\title{
HIGH-PRECISION U-PB GEOCHRONOLOGY AND LU-HF ISOTOPIC SYSTEMATICS OF ZIRCONS IN SOUTHERN AFRICAN CRATONIC MANTLE ECLOGITES AND IMPLICATIONS FOR SUBCONTINENTAL LITHOSPHERIC MANTLE EVOLUTION AND METASOMATISM
}

\author{
Mark Schmitz ${ }^{1}$, Steve Shirey ${ }^{1}$ and Rick Carlson ${ }^{1}$ \\ ${ }^{l}$ Dept. of Terrestrial Magnetism, Carnegie Institution of Washington, Washington DC, USA
}

\section{ECLOGITIC ZIRCONS}

Zircon is a trace constituent of a number of Group I eclogites from the Lace kimberlite (Group 2, $132+/-3$ Ma [Phillips et al., 1999], central craton) and Group II eclogites from the Lovedale kimberlite (Group 1, 74 +/$1 \mathrm{Ma}$ [Smith et al., 1994], southwestern craton margin) of the Kaapvaal craton of southern Africa. Highprecision ID-TIMS U-Pb isotopic measurements, and MC-ICPMS analysis of Lu-Hf isotopes on the same single zircon grains has revealed numerous episodes of zircon growth which provide insight into the timing of eclogite genesis and subsequent metasomatism of the subcontinental lithospheric mantle.

\section{LATE ARCHEAN ZIRCON AGES}

Single zircons from eclogites in both kimberlites yield near-concordant Late Archean (2.78 to $2.63 \mathrm{Ga}$ ) dates, providing a minimum age for eclogite formation. These Late Archean zircons also unequivocally establish the closed-system behavior of zircon with respect to $\mathrm{Pb}$ diffusion in these lithospheric mantle samples, and confirm the nature of recorded isotopic dates as crystal growth ages. In one Lace eclogite, extremely radiogenic initial $\mathrm{Hf}$ in an Archean zircon necessitates growth from a garnet precursor and a minimum eclogite model age of $3.0 \mathrm{Ga}$. On the other hand, similarities between zircon ages in the Lovedale eclogites and the timing of $2.7 \mathrm{Ga}$ intracratonic Ventersdorp mafic magmatism suggest a link with magmatic intraplating of the lithosphere (Armstrong et al., 1991). This link is supported by suprachondritic initial Hf of these zircons (Epsilon-Hf $=+7$ ), very near the inferred composition of the convecting upper mantle at $2.7 \mathrm{Ga}$.

\section{YOUNGER ZIRCON AGES}

In most of the Lace and Lovedale eclogites, Late Archean zircon is accompanied by younger phases of zircon, ranging from 0.95 to $0.16 \mathrm{Ga}$, which may date episodes of melt- or fluid-induced mantle metasomatism. In a craton-margin Lovedale eclogite, Mesoproterozoic zircon dates coincide with the latest stages of Kaapvaal-Namaqualand convergent margin orogenesis; initial Epsilon-Hf for these zircons ranging from +12 to -11 suggests the influence of both asthenosphere and lithosphere-derived metasomatizing agents. A Jurassic episode of zircon growth and accompanying phlogopite metasomatism is coeval with Group 2 kimberlite emplacement proximal to Lovedale, and the initial Epsilon- $\mathrm{Hf}=-20$ for this zircon supports a lithosphere-derived metasomatizing agent distinct from the Group 1 Lovedale kimberlite itself. In the central craton Lace eclogites, younger zircons have a range of near concordant dates from ca. 0.80 to 0.20 $\mathrm{Ga}$. The latter is the sole constituent in one eclogite nodule, and is precisely dated at $205.7+/-0.4 \mathrm{Ma}$ by three concordant zircons; these zircons also have 0.27 Ga depleted mantle Hf model ages and initial Epsilon$\mathrm{Hf}=+13$. This age significantly predates nearly all Group 1 and Group 2 kimberlite emplacement, as well as the rapid extrusion of the Karoo volcanics at $180 \mathrm{Ma}$. We suggest that this Jurassic eclogitic zircon growth in the lithosphere beneath the central Kaapvaal craton preserves a unique record of infiltration of asthenosphere-derived metasomatizing agents into the subcontinental mantle during the earliest stages of supercontinent breakup.

\section{REFERENCES}

Armstrong, R.A., Compston, W., Retief, E.A., Williams, I.S., Welke, H.J., 1991. Zircon ion microprobe studies bearing on the age and evolution of the Witwatersrand triad. Precambrian Res. 53, 243-266.

Phillips D., Kiviets, G.B., Barton, E.S., Smith, C.B., Viljoen, K.S., Fourie, L.F., 1999. ${ }^{40} \mathrm{Ar} /{ }^{39} \mathrm{Ar}$ dating of kimberlites and related rocks: problems and solutions. Proc. $7^{\text {th }}$ Int. Kimberlite Conf., Cape Town, South Africa, pp. 677-688.

Smith, C.B., Clark, T.C., Barton, E.S., Bristow, J.W., 1994. Emplacement ages of kimberlite occurrences in the Prieska region, southwest border of the Kaapvaal Craton, South Africa. Chem. Geol. 113, 149-169.

Contact: MD Schmitz, DTM/CIW, 5241 Broad Branch Road NW, Washington DC 20015, USA, E-mail:

schmitz@dtm.ciw.edu 